\title{
Obituary
}

Sir EdGeworth David, K.B.E., C.M.G., F.R.S.

$\mathrm{B}^{\mathrm{Y}}$ the death of Tannatt William Edgeworth David, emeritus professor of geology at the University of Sydney, Australasia has been deprived of an outstanding personality among her men of science. Although a brilliant geologist, the very breadth of his interests to some extent reduced his output of purely geological work, while the intensity of his enthusiasms sometimes led him to conclusions that his colleagues could not accept. But his reputation rests upon a broader and surer basis than his contributions to geological science, considerable as they were.

The outstanding feature of David's early work with the Geological Survey of New South Wales was the exploration and mapping of the northern coalfield, which has since become one of the main assets of the State. In 1891, he left the Survey to become the head of the new Department of Geology in the University of Sydney. In his new post his genius as a teacher was soon made manifest, and the glamour of his personality attracted an ever-increasing number of men and women students to what rapidly developed into one of the most vigorous and flourishing schools of a progressive university.

It is from 1907, however, when Ernest Shackleton passed through Australia on his way to Antarctica on his Nimrod Expedition, that the imperial and international reputation of David dates. One of the characteristics of the Permo-Carboniferous rocks that contain the main Australian coal measures is the evidence of a glaciation which may be said to be comparable in extent and intensity with that of the antarctic continent to-day. This fact captured David's imagination, and with characteristic foresight and energy he seized the first opportunity of studying a continental ice-sheet at first hand. Shackleton was not a man of science, but he was himself an intelligent and imaginative man, and saw the value of such a recruit to an expedition that was not too well-equipped on the scientific side. David obtained leave from his University Council to accompany the expedition as far as its base. When the Nimrod sailed for New Zealand again she bore with her-not Prof. David-but letters explaining his absence and asking for an extension of leave the granting of which he had already anticipated. South Victoria Land remained his home for twelve more months, and the scientific success of the Expedition was assured from the day his decision was taken.

David's part in the Expedition is well known. $\mathrm{He}$ led the first party to climb Mount Erebus, the successful ascent being undertaken when winter temperatures were already setting in. $\mathrm{He}$ carried through a detailed survey of what has proved to be the most interesting of all the winter quarters occupied by the expeditions to East Antarctica. $\mathrm{He}$ planned and executed as comprehensive a programme of scientific work as the equipment at his disposal allowed. Where equipment was lacking he often improvised with success means of observing and measuring accurately those factors of the antarctic environment which he thought would best repay investigation. $\mathrm{H} \Theta$ crowned his work by undertaking at the age of fifty-one years the first sledge journey to the South Magnetic Pole, a journey which involved more than a thousand miles of man-hauling, and might well have taxed to the uttermost the fittest of men in the prime of life. That he was exceptionally fortunate in the physique and determination of his two companions does not in any way detract from his own share in planning and executing perhaps the second greatest man-hauling journey that has ever been performed.

Beyond all this, David's contribution to the expedition must be measured, not by his physical or mental feats, or even by his scientific discoveries, but by the influence of his character and personality upon his leader and his comrades. In name and fact he was Shackleton's chief of scientific staff, but he became his chief adviser in other things as well. To the rest of us he brought a new conception of what loyalty and friendship might mean. None of our problems was too small to merit his attention : none so difficult that he could not make a contribution towards its solution. Whether he was assisting with a plane table survey, freezing his rather shaggy eyebrows to the telescope of a brass alidade in a gale at $-30^{\circ} \mathrm{F}$.; washing up after dinner with an inadequate ration of water; planning and installing a novel tide-gauge, adjusting the same gauge in a blizzard, or helping to rescue it from a sudden break-up of sea-ice; giving Dickens readings into the small hours in the winter night; or talking over with Shackleton the plans for the attack on the South Pole, the "Professor" was always equal to the occasion and always had some useful and original contribution to make. His courtesy and patience were only equalled by his good humour. Nearly all the good stories of the Expedition centre around one or other of these attributes, which were sometimes not without their trials to lesser men.

After the Expedition, Shackleton was cramped for money, and the publication of reasonably adequate scientific memoirs was almost wholly dependent on David's activities. He lectured all over Australia in search of funds, and he devoted a great deal too much of his own slender resources to the same end. Funds proved difficult to raise, and the memoir which was David's chief published contribution to geology did not appear until 1914. It still remains the chief authority on general antarctic geology, and that aspect of the work is David's alone.

When the War broke out, Prof. David was fiftysix years of age, but he threw all his energy into the recruitment and training of an Australian mining unit and, when the time was ripe, repeated his exploit of 1908 by accompanying the expedition overseas. In France he spent some busy months in congenial geological work on the Western Front, until in 1917 occurred the accident from which he never wholly recovered, although he was still to carry out many 
years' useful work. When descending a well shaft to examine the rocks through which it had been dug, he fell some 70 feet and was very seriously injured. The two remarks he is reported to have made when he recovered consciousness are perhaps as characteristic as anything he ever said. His first was: "It was, I assure you, solely my own fault. No one else is to blame." Then, turning to the unfortunate officer in charge of the winch : "You let me down so fast that I was unable to make out the sequence of the strata as I went past."

After his recovery, David was attached as chief geologist to General Headquarters and there he remained until the Armistice, one of his duties, which caused him a deal of quiet amusement, being the location of underground workings to protect the General Staff from bombs. He returned to Australia in 1919, and the next news his friends in Europe had of him was that he had departed on camel-back on an expedition to Central Australia in company with another veteran geologist, Howchin, of the University of Adelaide, who must then have been more than seventy years of age.

The last years of David's life were shadowed to some extent by illness, by the controversy that arose over his claim to have discovered preCambrian fossils, and by his failure to complete his last self-imposed task, the preparation and publication of a comprehensive account of Australian geology, which was the main preoccupation of the years after his retirement from the headship of his Department in 1924. In 1932 he fortunately published a geological map of Australia with a volume of notes as an instalment of the great work, which he was himself beginning by then to fear he had commenced too late. Two days before the announcement of his death, the present writer received a letter concerning a projected visit to Cambridge in the winter, when he hoped to spend some months at Clare, the college of his adoption there, completing his book, so that he was, as he would have wished, in harness to the very last. His country, the scientific world and a host of friends are the poorer by his death.

R. E. P.

\section{Prof. C. O. Jensen}

Prof. Carl Oluf Jensen, who died on September 3 at the age of seventy years, was professor of pathology and director of the Serum Laboratory of the Danish Agricultural and Veterinary School, Copenhagen. He was chiefly honoured, and will be best remembered, as the author of two classical papers in cancer research-the first in 1903 on the experimental propagation of an alveolar carcinoma of the mouse, and the second in 1909 on transmissible rat tumours.

Although the transmission of rodent new growths had previously been achieved by Moreau, Hanau, and L. Loeb, Jensen's researches are rightly regarded as the beginning of modern experimental cancer research. He showed that the new tumours arose from the intact cells inoculated, and not by a trans. formation of the tissues of the new host. He further investigated the conditions for survival of tumour cells outside the body, proving that successful transmission could be obtained with tumour material after three weeks' sojourn in the ice-chest. The prompt and complete confirmation of his results by Bashford and myself no doubt assisted the general recognition of the advance made by Jensen, but its fundamental nature was really established by Jensen's own work and by his free and wide distribution of tumour material. The award of the Walker Prize of the Royal College of Surgeons in 1906 was made in recognition of the value of these researches.

The transmissible rat sarcomas which formed the subject of Jensen's second paper are better known and have been propagated and used for investigation in every cancer laboratory in the world, but the remarkable circumstances of their origin have either been forgotten or ignored. They arose in two rats inoculated intraperitoneally with cultures of an acidfast bacillus, a remarkable and unexplained observation which has never been repeated.

Jensen's only other contribution to tumour problems dealt with the transmissible tumours of the turnip and beet, later shown by Erwin Smith to be due to a microbe (B. tumefaciens) and now familiar as crown-gall.

In later years, administrative duties in connexion with Denmark's paramount agricultural industry absorbed so much of Jensen's time and energies that cancer research was perforce relegated to the background. His fame is secure and his memory will be cherished as long as men busy themselves with the fascinating problems of cancer.

\section{J. A. Murray.}

WE regret to record the death on September 24, at the age of seventy-seven years, of Mr. C. Carus-Wilson, who will be remembered for his investigation of the phenomenon of 'singing sands'. So long ago as 1888 , Mr. Carus-Wilson read a paper before the Bournemouth Natural Science Society in which he ascribed the production of sound by certain sands to the rubbing together of myriads of very smooth grains of quartz. In Nature of August 6, 1891, he described further experiments in which he succeeded in producing musical notes from appropriate sands in vessels of various shapes and sizes. He was able to show that Eigg sand in particular is musical in any vessel, whereas other 'singing sands', such as those of Studland Bay, emit sound only in highly glazed vessels of particular shape. A process of sifting, washing and boiling was also used to improve the emitting power of poorly musical sand. Mr. CarusWilson was a successful lecturer and writer on geological and other science subjects.

WE regret to announce the following deaths :

Sir John Adams, from 1902 until 1922 professor of education in the University of London and principal of the London Day Training College, on September 30, aged seventy-seven years.

Prof. Adalbert Fernau, director of the Institute for Radium Technology at Vienna, on August 30, aged fifty-six years. 